\section{Fermentation of Wood-dust by Cellulose Bacteria}

IN this laboratory, fermentation of birch, aspen and pine-dusts has been investigated by enrichment cultures of thermophilic ${ }^{1}$, and recently also of mesophilic ${ }^{2}$, cellulose bacteria. he Tfiner the wood was ground, the more of the cellulose was fermented. In the best cases, a fermentation of about 70 per cent of cellulose in wood was obtained with the leaf-tree dust at $60^{\circ} \mathrm{C}$. Distinct fermentation could be noted only a day after inoculation. Our results have thus disproved the earlier conception that the cellulose in wood is fermented only when lignin is in some way destroyed $^{3}$, and are evidence against the supposition that cellulose and lignin are chemically bound in wood. Nevertheless there may be such a linkage, for the long cellulose molecules may be broken on grinding wood. If we presume that lignin is bound to the other end of the fibrous cellulose molecule, there would be formed from the free end of these molecules fragments which afford a suitable substrate for bacteria. As lignin is decomposed to some extent during fermentation (in one experiment with birch dust the decrease in the lignin content was 11.4 per cent, and in methoxyl content 29.2 per cent) the bonds between lignin and cellulose can also be broken, so that even the cellulose bound with lignin becomes fermentable. The assumption that a part of the cellulose in wood is bound with lignin, while a part is free, is in accord with our findings. This would also explain why the whole amount of the carbohydrates in wood-dust could not be fermented.

One of our observations made in connexion with cellulose fermentation deserves particular attention. The volume of gas first formed in the thermophilic fermentation decreased during further fermentation, if the gas trapped in the burette was in contact with the fermentation flask. Thus at the end of fermentation there might be found less carbon dioxide than was liberated from calcium carbonate by acids formed in fermentation. In such cases the gas mixture contained no hydrogen. In fermentation experiments where some carbon dioxide was developed, hydrogen was also formed in some measure. These findings and the great amount of acetic acid formed in fermentation showed that carbon dioxide is used for synthesis during fermentation. Presumably acetic acid is thereby formed, according to the equation : $4 \mathrm{H}_{2}+2 \mathrm{CO}_{2}=\mathrm{CH}_{3} \cdot \mathrm{COOH}+2 \mathrm{H}_{2} \mathrm{O}$. Wieringa ${ }^{4}$ has noted such a reaction with Clostridium aceticum.

Also with mesophilic cellulose bacteria (enrichment cultures from the rumen of sheep) Koistinen ${ }^{2}$ has recently noted an active synthesis of acetic acid from the gases formed in the fermentation of wooddust. When carbon dioxide was added to the system, acetic acid was formed corresponding to 130 per cent of the fermented holocellulose, while carbon dioxide was simultaneously consumed. In this case the reaction seems to have proceeded primarily according to the equation: $\mathrm{CH}_{4}+\mathrm{CO}_{2}=\mathrm{CH}_{3} \mathrm{COOH}$. The reaction may also occur partly through the reduction of carbon dioxide caused by hydrogen, as has been assumed in connexion with the thermophilic fermentation. The combination of carbon dioxide has been noted only in an acid reaction $(p H+6 \cdot 0-6 \cdot 5)$.

The building up of fatty acids in cellulose fermentation through the reduction of carbon dioxide suggests new views of the activity of the rumen. The large amount of carbonates which goes in saliva to the rumen may be used up for the synthesis of fatty acids. The amount of gas formed in the rumen may, in turn, essentially depend on this synthesis, which, again, is determined by conditions in the rumen.

Biochemical Institute, ArtTuri I. Virtanen

Helsinki.

Oct. 23.

${ }^{1}$ Virtanen and Koistinen, Suomen Kemistilehti B, 11, 30 (1938). Svensk Kemisk Tidskrift, 56, 391 (1944). Virtanen and Nikkilă, Suomen Kemistilehti B, 19, 3 (1946). Virtanen and Hukki, Suomen Kemistilehti $B, 19,4$ (1946).

${ }^{2}$ Koistinen, Suomen Kemistilehti $B$, in the press.

${ }^{3}$ Olson, Peterson and Sherrard, Ind. Eng. Chem., 29, 1026 (1937). 4 Wieringa, Leeuwenhoek, 3, 1 (1936); 6, 251 (1939-40).

\section{Symbiosis of Azotobacter with Insects}

IN 1912, I published (Ber. d. bot. Ges.) a preliminary note on the constant symbiosis of Aphides with Azotobacter. The entomologist, Prof. K. Sule, of Brno, had previously (1910) found that the hitherto mysterious function of an organ in aphides and similar insects, called the pseudovitellus, was a seat of symbiotic organisms. I succeeded in isolating and identifying them as belonging to the genus Azotobacter, and in 1916 published the results of my studies in the Prague Zemedelsky Archiv.

Owing to difficult and unfavourable circumstances it was not possible for me to devote much further attention to the subject until recently, when I discovered that the organisms in the mycetocysts or mycetomes (pseudovitellus) procure for the insects free nitrogen from the air for the synthesis of proteins that are primarily necessary for producing the enormous quantity of eggs and young. I have now also found instances of Azotobacter symbiosis in Lecanium Persica, Limothrips (which absorb sugars from plants in the same way as aphides, cycades, etc.), in the larvæ of the beetle Anobium paniceum, in the imago of the grain beetle Sitophilus, in the larvæ of the moth Sitotroga cerealella, and in the larvæ of the 'bark-boring' beetle Eccoptogaster rugulosus. These insects would starve for lack of nitrogenous food were it not for mycetome symbiosis with Azotobacter.

I have concentrated my attention on the disastrous epidemic now raging in the spruce forests of Czechoslovakia, caused by, the bark-boring beetle Ips (Bostrychus) Typographus L. This epidemic is a result of the ruinous economy practised during the German occupation.: The beetle multiplied in the borderlands where the felled tree trunks supplied plenty of food, and from these trunks infection spread to healthy trees.

Possessing no laboratory (my Institute at the Agricultural and Forestry School was plundered by the Germans), I confined myself to microscopical examinations. The eggs and very young larvæ were found to contain large numbers of the Azotobacter. In this respect Ips resembles aphides. The method consisted in crushing and smearing material from the organs, fixing with a flame, removing fat with xylol, alcohol, water and blue cotton, and then mounting in Canada balsam.

Longitudinal sections through a young larva of Eccoptogaster revealed large masses of intact Azoto. bacter zooglœæ in the peripheral layers of the tissue, whereas in the digestive organ of the same larva a mass of Azotobacter was being digested, with the 